\title{
MEDIA POLICIES OF THE STATE IN THE TIME OF COVID-19
}

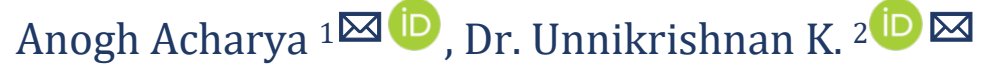 \\ ${ }^{1} \mathrm{PhD}$ Fellow, Manipal Academy of Higher Education, Manipal, India \\ ${ }^{2}$ Associate Professor, Manipal Academy of Higher Education, Manipal, India
}

D0I: https://doi.org/10.29121/granthaalayah.v9.i3.2021.3800

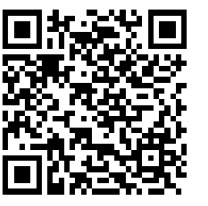

Article Type: Research Article

Article Citation: Anogh Acharya, and Dr. Unnikrishnan K.. (2021). MEDIA POLICIES OF THE STATE IN THE TIME OF COVID-19.

International Journal of Research GRANTHAALAYAH, 9(3), 211-220. https://doi.org/10.29121/granthaa layah.v9.i3.2021.3800

Received Date: 05 March 2021

Accepted Date: 31 March 2021

Keywords:

Media Policies

Development Communication

Public Policies

C-DOT

CQAS

Positive News

POD Framework

\begin{abstract}
Media and communication management during pandemic is very crucial to development process of the nation. This paper analyses four (public) policy level actions of India, through its media units and ministries viz., MIB, MoC and MeitY. It uses a self-curated analytical framework, under three themes to study the policies and discusses their relevance and effectiveness. From C-DOT's launch of communication strategies, to facilitating smooth operations of media, to curbing misinformation on Corona virus and representing "positive news", an in-depth analysis has been conducted based on the designed framework.
\end{abstract}

\section{INTRODUCTION}

The year 2020 was bad but it was not the worst year in human history. From 1348's Plague, to 1644's collapse of Ming Dynasty and Thirty Years War of Europe, to 1919's Spanish Flu, to 1944's Holocaust and World War II, we have witnessed worse and have lost millions more (Berhnhardt, 2021).

The entire diaspora of communication has been changing. The audience which was once a passive listener being part of the one to many unidirectional communication flow is different now. The COVID pandemic has brought this issue into a brighter light. The current active audience can and are respond(ing) more effectively than the communicators due to the boom of media and especially social media (Smith \& Wanless, 2020). This has emerged as a challenge for behavior change communication model as every transmitted information incurs reaction from various audiences. These reactions get infused with the original message and reaches people further down the information chain. Such phenomenon results in the Chomsky's concept of "Information Pollution". It is the answer to his iconic question, "Why do we have so much information, yet know so little?". The social media platforms like 
Media Policies of the State in the Time of Covid-19

Instagram, which is now partially merging its user interface with Facebook owned Messenger, is now being the new Messenger. Thus, Messenger and apps like them are evolving as the literal messenger of the present time.

Earlier in year 2020, WHO had asked all the Instagram influencers to speak about the COVID safety guidelines provided by them. This clearly is an example of the fact that the general mass adheres more to the Instagram content than the messages through the official establishments. Social media works as a platform for social approval of the legal and official statements of the official bodies, for Generation Y. Chomsky (1988) stated, "The general population doesn't know what's happening and it doesn't even know that it doesn't know", and surprisingly it is valid now too.

India has ranked 86 out of 98 countries by an Australian think tank, Lowly Institute in COVID- 19 handling. The best performing nation was New Zealand. While USA ranked 94, China was not included in the list due to the unavailability of publicly available data. (IANS, 2021)

There was a lot confusion in regard to the COVID precautionary measures. There was uncertainty about new scientific data and analysis. The best of the best were clueless, authorities were unaware and torchbearers were missing. Almost every day there was a new theory, every month there was a new guideline. It was hard to keep up with the speed at which events unfolded and information changed. Public health officials were not being able to be confident with their recommendations or at least that's what appeared to be. (Smith \& Wanless, 2020)

In such situations of uncertainty, responsibility falls upon the fourth estate of the state- Media. Media entwines political, ideological and economic processes in the society. It has got far reaching in such dynamics and really is just not a mean for transmitting information. As McLuhan (1964) stated, "Medium is the message", media and communication has thus, evolved to be viewed as a social process. Just like communication, the methodological understanding of development is also constantly evolving. These changes meet within the hypernym, Devcom (Development Communication). This term is itself going through a constant terminological evolution. From 2019, onwards Media has been gifted with another opportunity in the Devcom field; the responsibility to counter the exponential growth of Corona Virus. However, for any such development endeavors, the central element lies in public policies, especially in a policy rich nation like India. They are essential in such a democracy for steering development (Narain, 2018). Ground level intervention guided by a sound public policy is essential for building a climate, for behavioral change.

\section{REVIEW OF LITERATURE}

\subsection{COMMUNICATION MANAGEMENT IN PANDEMIC}

During pandemic situations, interaction of the population can be very influential. Thus, communication should be effectively used as a medium to prevent the spread of the virus and reduce the adverse effects that are associated with it. The role of social media, especially, has been essential in understanding the virus and its associated implications. The communication management is one of the key challenges faced by the authority during such times. (Demuyakor, 2020; Limaye et al., 2020)

A report published by New America (2020), provide suggestions to policymakers in U.S. Government for combating the spread of misinformation during this pandemic. Although

U.S.A performed poorly in managing the pandemic, these suggestions are beneficial and can referred for the Indian policymaking as well. The recommendations are :

1) Policymakers should enact rules to require greater transparency from online platforms, including regular reporting regarding their content moderation, ad targeting and delivery

2) Enforcement of Section (5)(a) of FTC (Federal Trade Commission) Act i.e Measures against business that engage in deceptive trade practices including online ad campaigns and e-commerce

3) Government agencies and representatives should ensure the dissemination of verified information related to the pandemic

4) Government public health officials and relevant agencies should collaborate with internet platforms to provide and promote verified information related to the pandemic on their platforms

5) Clarification of the fact that all offline anti-discrimination statutes apply in digital environment

6) Funding of vetted fact checking organizations around the world to tackle the growing volume of COVID-19 related misinformation.

(Singh \& Bagchi, 2020)

International Journal of Research -GRANTHAALAYAH 
Anogh Acharya, and Dr. Unnikrishnan K.

\subsection{SOCIAL MEDIA AND COVID-19}

Web-based media has demonstrated to be quite possibly the main vehicles that can be utilized to disperse data with respect to dangers and threats of a specific phenomenon; in this case, the COVID-19 (Kushner, 2020). 21st century's system of Infomedia is led by social media, and this medium is even faster than corona (Aisha et al., 2015; Depoux et al., 2020). This pace of the medium invites the scope of the spread of misinformation, as well, often in the subtlest way possible. Thus, fact checking becomes difficult with layers of misinformation around the truth.

The two-fold role of social media was to provide description of the reality and inform people about the control measures against the virus, to shape a new reality (Demuyakor, 2020; Kushner, 2020). Demuyakor (2020) wrote -

According to CDC (Centre for Disease Control), it is essential to include social media in the development of both local and national plans as far as the pandemic and associated risks are concerned. Institutions must see social (media) as part of the solution and response effort, and be able to include it during planning or any form of preventive exercise.

Thus, building strong relationships between various government structures or authorities and social media management will be beneficial for governance, through induced behavioral changes in such media consumers. Strong public policy level actions based on coordinated social media participation of people will result in effective management of the pandemic situation (Chen et al., 2020).

\section{Journalism}

In a democracy like India, journalism has a crucial role to play as it is seen as a platform for "objective information" and "critical rationale discourse" (Singh, 2020). Journalists are the torch bearers of truth and truth scares power. Thus, journalism pushes authorities to be dutiful and work towards the betterment of the society with honesty and in ethical way.

\section{Changing Media and Entertainment Landscape}

As the world is shifting towards a new 'normal', consumer behavior is adapting and evolving. The already growing digital platform has started accelerating now. The home isolation and work from home environments has worked as a catalyst. Most of these changes are not temporary in nature. Even though the pandemic is over, the psychological hangover would make audience comfortable with the new M\&E(Media and Entertainment) landscape. The digital is the future. By 2030, India will have a billion digital users will form a new confident landscape with digital 'citizenry' (Menon, 2020)

Thus, the need of the hour is understanding the policy level actions of Government in managing and regulating media through the prism of development communication, especially when there is a fear of second or third wave hitting us soon.

\section{METHODOLOGY}

This research studies the policy content of regulatory media based policies. This paper attempts to study the (public) policy level actions of India, through its media units and ministries namely, Ministry of Information and Broadcast (MIB), Ministry of Communication (MoC) and Ministry of Electronics and Information Technology (MeitY), during the time of COVID-19, under the NDA government regime, in the development discourse of India. It is an explorative qualitative study, in which judgement sampling is used to choose the necessary policies.

This policy level study uses a self-curated framework inspired from the POD framework (Melkote \& Steeves, 2015), to analyze and reflect upon the chosen media policies of the state. This will help in understanding the direction of Indian media policies for COVID-19 and thus open gateways for building sound public policies, in near future.

\section{SAMPLE}

Out of various policies designed during the corona virus outbreak, four important media policies of Government of India are shortlisted for analysis. The chosen policies are:

- Advise to Media owners to represent "positive news" related to COVID-19. (Sagar, 2020)

- Advisory to curb false news/ misinformation on Corona Virus (MeiTY, 2020) 
Media Policies of the State in the Time of Covid-19

- Instruction to state to facilitate smooth supply and distribution chain for media operators (MIB, 2020)

- C-DOT (Centre for Development of Telematics)'s launch of COVID-19 Savdhan, Arogya Setu IVRS(Interactive Voice Response System) and CQAS (Covid-19 Quarantine Alert System) (DoT, MoC, 2020)

Some other policies related to the pandemic situation are as follows:

- SOPs for Exhibition of Films on preventive measures to contain spread of COVID-19; dtd. 6/10/2020 (MIB, 2020)

- Allotment of short code '1499' as Helpline 'Corona Santvana' to treat patients who suffer from insomnia, depression and other mental elements due to Corona to Forest and Environment Department, Government of Gujrat; dtd. 17/7/2020 (MoC, 2020)

\section{DATA ANALYSIS}

The analysis of data helps in 'inspecting, cleansing and modifying' the collected data to bring clarity and identify useable information (Xia \& Gong, 2015). Following the curated analytical model, as explained in methodology chapter (page no. 15) , the sample policies are analyzed. The analysis is as the following:

1) Advise to Media owners to represent "positive news" related to CoVID-19. According to a Caravan article of March 31st, 2020 "Around six hours before Prime Minister Narendra Modi announced a threeweek nationwide lockdown, on 24 March, he personally asked over twenty owners and editors from the mainstream print media to publish positive stories about the COVID-19 pandemic. The owners and editors represented media organizations working in 11 different languages, including the senior-most members of national media houses such as the Indian Express Group, the Hindu Group and the Punjab Kesari Group" (Sagar, 2020)

This was followed by an advisory from MIB to the Editors Guild of India.

\section{Proposed Action}

Existing Model/ Mechanism: A similar situation was practise post the 2002 Gujrat Riots, where five positive news were asked to be telecasted by the then Government of Gujrat to the local news channels of the state.

Need Felt: The chaos and misinformation regarding COVID-19 was creating panic amongst the general population. The philosophical need in such a scenario to spread positivity and hope among the people of the nation.

Expected Result of Action: Invoking a heightened sense of nationalism and assurance on the right functioning of the state missionaries. The purpose was to keep the nation united towards the cause of fighting pandemic.

Actual Outcome: However, the reality or the perceived reality based on the numbers of COVID-19 deaths and affected patents were so high that even a positive approach couldn't stop the panic mode of the people. Some were panicked and some were masked with the coloured reality and some were just patiently waiting for the pandemic to phase to out, eventually.

\section{Guiding Principle}

The principle behind such a thought is to motivate the nation as a unit and providing hope and faith in such times of despair. However, the principle of Journalism thrives on honesty. So the main question that arises is whether the general public should be kept in dark about

realities, that might not bear the tag of "positive" news.

Execution / Implementation

Executive Mechanism: The newspapers wrote stories on the success of the national Government bodies in countering the pandemic situation in comparison to other nation. However in reality, India was comparatively a poorer performer in the global scenario, ranking 86 out of 98 nations.(IANS, 2021)

Agency Implements: All major news media houses. It was not limited to Newspapers only rather this approach was extended to the news channels telecasting though TVs and smart phones.

2) Advisory to curb false news / misinformation on Corona Virus (MeiTY, 2020) According to the second paragraph of advisory no. 16(1)/2020-CLEDS, "Social media platforms are intermediaries as defined under section 2(1)(w) of the Technology Act, 2000 and are required to follow due diligence as prescribed in Information Technology (Intermediary Guidelines) Rules 2011 notified under section 79 of the IT Act. They must inform their users not to host, display, upload, modify, publish, transmit, update or share any information that affect public order and unlawful in way" 


\section{Proposed Action}

Existing Framework/ Mechanism: The Govt. of USA was amongst the first in the world during pandemic to send such advisories to the respective authorities. However, the problem of fake news or misinformation is not an entirely new issue for India. In recent times, pro Govt. bodies also had been part of fake news spreading culture. New agencies like AltNews and other fact checking agencies were constantly trying to bust such news made by people from both the sides of the political spectrum. Websites like Postcard have made a successful business model with false news and provocative headlines (Kumar, 2017). In past, there had been concerns regarding the need for social media guidelines and a social media framework/guideline for Government organizations had been proposed. Department of Electronics and Information Technology under the then Ministry of Communication and Information Technology had provided a report on the same (Dept. of Electronics \& IT, 2015).

Need Felt: Excessive spread of misinformation due to the existence of influencers in social media and their varying multiple contents that were conflicting against each other and increasing further confusion amongst direct and indirect consumers of such content and information.

Expected Result of Action: Countering the spread of misinformation and bringing one truth and one reality of the pandemic situation, out to the people.

Actual Outcome: The spread of false news was restricted to quite an extent, although there were global players as well whose policy efforts worked as a catalyst, or the other way around, in the domain of social media.

\section{Guiding Principle}

Unlike the previous policy, the guiding principle in this one was that of factual reality. Since, it was a health related issue, it was crucial for the mass to be aware of the intricacies of the matter. Following any wrong instructions would escalate the situation further, increasing the spread of the virus and more death tolls. The aspect of maintaining a communal harmony was also important by curbing fake news.

\section{Execution / Implementation \\ Executive Mechanism:}

- Initiating awareness campaigns on the platforms for the users to not circulate or upload any false news

- Immediate action to remove such content on priority basis and dissemination of authentic information only

- A link to WHO's official guidelines were provided whenever any COVID-19 related posts were made in social media. WHO had also sent a direct message to all the social media influencers to cooperate and help for the cause of spreading the right information.

Implementing Agency: All Social Media Platforms. However, the Facebook owned Instagram and Twitter had been very successful in implementing them. The increasing count of Instagram influencers and the 'story' feature of the app has reached many people.

\section{3) Instruction to state to facilitate smooth supply and distribution chain for media operators (MIB, 2020)}

As published in the Economic Times (2020), "In a letter to chief secretaries of all states, the ministry of information and broadcast said that the functioning of the media network was essential to create awareness among people, to disseminate important messages and also keep the nation updated on the latest status". By emphasising on the importance of newspapers in uniting communities during pandemic, the ministry wrote, "False and fake news need to be avoided and good practices need to be promoted and these networks play a pivotal role in ensuring the same". (ET Bureau, 2020)

\section{Proposed Action}

Existing Mechanism: This is a common phenomenon; occasionally such instructions from Central Government are provided to the State Govt.

Need Felt: Even though the lockdown was over, the government of various states were ensuring limited movement of people within cities and towns. This was affecting the news coverage and limiting the Government to showcase their progress of the managing the pandemic situation. This was also required to counter the fake news generated through social media. 
Expected Result of Action: State government's facilitation for efficiency of supply and distribution chain of the media houses. The order of the ministry expected state to cooperate by permitting, the movement of "accredited staff of service providers, media vehicles" and required provisions.

Actual Outcome: The majority of the states did comply with these instructions with few exceptions like that of West Bengal where journalists and media houses identified as supporters of BJP (Bharatiya Janta Party) were not provided free access and cooperation by the workers of AITMC (All India Trinamool Congress) (Singha, 2021). However, eventually, that issue was resolved too and the political angle got side-lined.

\section{Guiding Principle}

"Newspaper is important in uniting communities during a public health crisis and so is its role in informing, warning and preparing people to survive and rebuild during an emergency" (ET Bureau, 2020)

\section{Execution / Implementation}

Executive Mechanism: There was no fixed mechanism for such an instruction or order as such. Each state had their own way of ensuring that they facilitate media operations. Moreover, the State Governments did comply with the order with immediate effect, apart from few exceptions. This policy level action was successful, indeed.

Implementing Agency: State Government, Media Ministries of the State and Police forces.

\section{1) C-DOT (Centre for Development of Telematics)'s launch of COVID-19 Savdhan, Arogya Setu and CQAS (DoT, MoC, 2020)}

- COVID-19 Savdhan: This application enabled authorities to reach out to all mobile subscribers in any particular containment zone. The name 'Savdhan' means 'Be Aware' in Hindi.

- Arogya Setu IVRS (Interactive Voice Response System): The launch of the Arogya Setu IVRS by the Ministry and development by C-DOT was done for landline users and feature phone. The name 'Arogya' means 'Bridge to Health' in Sanskrit.

- CQAS (Covid-19 Quarantine Alert System): With the means of a SOP (Standard Operating Procedure) shared between DoT and all telecom service providers, the CQAS application was developed by C-DOT. With this data from phone, including a device's location, is collected and stored in a common secure platform.

\section{Proposed Action}

Existing Model/ Mechanism: Around the same time but prior to it, the normal Arogya Setu app was launched and everyone in the nation was instructed to download. It was mandatory for traveling and attending public events or gatherings. However, there was no other such methods of collecting personal data by the Government for health security, that was publicly acknowledged, prior to this

\section{Need Felt:}

- Need to reach people on an individual level and communicate the desired messages related to COVID-19 protection and reliefs.

- Only smartphone users were able to use Arogya Setu application and get updated whether they have come in contact with COVID-19 person and the possibility of contracting the virus. The others were left out of the process.

- Need of a mechanism to keep a check on people in quarantine zone and ensure that they don't break the quarantine / isolation protocol.

\section{Expected Result of Action:}

- Better reach of information through SMS as the message would directly delivered to mobile handsets that people carry with them always.

- Information from non-smart phone holders would also be collected and thus creating a bigger information pool

- Receiving information about protocol bleachers.

Actual Outcome: Since, the success of the entire plan depended upon the people and their response, this policy could be termed as highly ambitious. People in order to serve their personal interest and also in fear of being labelled 
Anogh Acharya, and Dr. Unnikrishnan K.

as a COVID-19 patient, often gave wrong information. Although in most cases, the assumption that people would be providing the correct data was falsified, yet people somehow believed that these mechanisms are highly intelligent enough to protect from COVID-19 and possibly cure them. Although, most of the people didn't give the right information but many people did adhere to the instructions provided. Hence, though these systems failed to execute with accuracy what it was designed for, it did have a placebo effect on the people.

There was also a major blow to these plans, especially to CQAS, when millions of personal data were proved to be hackable by third party. The low security issue is not uncommon in Govt. based systems, including the original Arogya Setu App that stores personal data of the people (Bhargava, 2020; Clarance, 2020).

\section{Guiding Principle}

Awareness for people and awareness of people. The Govt. wanted to take control of the

situation by gathering details about the affected victims and aware people about the precautionary measures related to COVID-19.

\section{Execution / Implementation}

Executive Mechanism: According to the quarterly newsletter of DoT, Ministry of Communication (June, 2020)

- "The Govt. could reach up to the level of individual mobile tower, by sharing the SOP (Standard Operating Procedure) with all mobile networks and convey targeted messages about health, wellbeing, water supply etc. by means of SMS in local language".

- "The IVRS is toll free service where a feature phone and landline user will have to give a missed call to the number 1921 and the caller will be contacted requesting for inputs regarding the health."

- "CQAS prepares a list of mobile numbers, segregates them on the basis of telecom service providers. The location data provided by the telecom companies is run on the application to create a geo fencing (accurate up to $300 \mathrm{~m}$ ). The location information is received periodically over a secure network for the authorized cases 'due protection of data received'. In case a person escapes from isolation or jumps quarantine, the system sends SMS and E-mail alerts to the authorized government agency"

Implementing Agency: DoT of Ministry of Communication, GOI and C-DOT

with the help of all telecom service providers viz. Jio, Airtel, Vodafone-Idea, BSNL, Aircel etc.

\section{INTERPRETATIONS AND DISCUSSION}

Tomas Gray (1768), had written in his Ode titled, 'Ode on a Distant Prospect of Eton College', "Ignorance is Bliss". So, the choice is between knowing the truth and being unhappy or be happy and ignorant. However, any happiness based on ignorance is a house of cards that always demands more lies and victims to keep it standing. 'Positive news' is a smartly coined term which actually means pro Government news. Singh (2020), asks an important question in his EPW article, "Why would media houses follow government diktat rather than investigating the real state of affairs, unless they have associated business interests?". If Media can't be critical to Government, then it has to knock some other doors for content, as Media loves making a bold statement. That's why there's a constant need for sensational content value, that is decreasing the content of the news.

Attempt to stop the spread of fake news is ironical if only half of the truth is shown to the people; the "positive" half. In order to truly counter fake news, the truth should be acknowledged; "the whole truth and nothing but the truth" i.e the full and unvarnished truth (Indian Oath Act, 1873). Social media has been identified as a medium for the spread of misinformation, as there is no fact checking process for the content that's released to the world. Social media provides voice to all, immediate outreach and twenty-four into seven engagement (Dept. of Electronics \& IT, 2015). In spite of the significant concerns regarding the use of social media, social networking is a very vital tool for knowledge sharing (Das \& Ahmed, 2020). Social media has also helped reduce psychological impacts on people to an extent during COVID-19-led lockdowns and isolations (Chen et al., 2020). It provides the Government agencies to engage with the stakeholders in real time and thus enforcing a citizen centric policy making process. However, the power of the reach of Social Media can be both a curse and a boon, like two sides of a same coin.

Media is very powerful and influential; and journalism is the torch bearer of it. Information empowers people. However, it should be ensured that the information is factual without bearing any political color. It is unimaginable for Govt. to execute such a mechanism because there is always a political party in power, but by putting out with the faith on the Indian judiciary system, it is not impossible; if correct policies are made and enforced. 
During the pandemic, the Govt. has taken many bold and innovative steps and we truly appreciate the efforts, but how productive was it? According to the quarterly newsletter of Department of Telecommunications of MoC (Ministry of Communication), for the quarter ending June, 2020, there was substantive amount of decrease in tele density. There was a decrease $14.45 \mathrm{M}$ (million) telephone connections; from $1176.80 \mathrm{M}$ to $1162.35 \mathrm{M}$. By the end of June, tele density decreased to $85.98 \%$ from $88.66 \%$. The rural tele density is $58.89 \%$ in comparison to $138 \%$. Although there had been an increase in overall internet penetration (broadband and narrowband) with a quarterly growth of 3.4\%, the number of broadband subscribers have decreased by 3.7 million (appx.). It was during this time; $\mathrm{C}$-DOT was launching various programs under MoC. The ground reality of the nation seemed distanced from the vision that the Government had. (DoT, MoC, 2020)

The development of the nation must begin in the grass root, then only innovative measures could be made use of, in the best possible way.

\section{CONCLUSION}

In Policy evaluation study, politics enter evaluation at all levels as choosing what to be evaluated is in its own a political act (Narain, 2018). Dye (2002), wrote "Politics decide what policies and policy alternatives will be studied in the first place". So it is very important to be the improbable, be apolitical and yet factually scrutinize the policies. Just like the importance of being unbiased is in policy evaluation, honestly and bottom-top approach of development is equally important in policy formulation.

The media was once seen as a medium for informing people about policies but now there are policies for media itself. It has made the journey from 'media for policies' to 'policies for media'. Pandemic situations like COVID-19 has shown us once again the importance of media in controlling the people for the benefit of themselves and the nation. Media management has become an important aspect in steering development of the nation. For managing media, especially of the state, there should be media based policies and they should also be documented properly, so that they can be studied and analyzed for the betterment of the state and its functionaries.

Since, the impact of media has already proved to be resulting in behavioral changes of people, it is essential that policy think tanks are established, focusing only on the aspect of media functionaries of the state; especially in a policy rich nation like India. It is time to go back to the days of Dr. Vikram Sarabhai's SITE project and use media with its full potential for development endeavors. We need developmental communication or as it is said now a days Communication for Development.

\section{SOURCES OF FUNDING}

This research received no specific grant from any funding agency in the public, commercial, or not-for-profit sectors.

\section{CONFLICT OF INTEREST}

The author have declared that no competing interests exist.

\section{ACKNOWLEDGMENT}

Authors would like convey their regards to Prof. Vardesh Hiregenge, HOD of GCPAS, MAHE for his valuable feedbacks, Ms. Rathee, Head Librarian, MIC for her help in plagiarism check, and Mr. Anindya Acharya and Mrs. Sathi R. Acharya for their contributions.

\section{REFERENCES}

[1] Agugna, R. (2019). Towards a Professionalising of Communication for Development: A Strategy for Improving Aid Effectiveness. Asia Pacific Media Educator, 29(2), 123- 136. 
Anogh Acharya, and Dr. Unnikrishnan K.

[2] Aisha, T. S., Wok, S., Manaf, A. M. A., \& Ismail, R. (2015). Exploring the Use of Social Media During the 2014 Flood in Malaysia. In Procedia - Social and Behavioral Sciences (Vol. 211, pp. 931-937). https://doi.org/10.1016/j.sbspro.2015.11.123

[3] Anderson, J. (2010). Public Policymaking (7 ed.). New York: Cengage Learning. Back, A., Tulsky, J. A., \& Arnold, R. M. (2020). Communication Skills in the Age of COVID-19. Annals of Internal Medicine, 172(11), 759-760. https://doi.org/10.7326/M20-1376

[4] Baxi, U. (2009). Humman Rights in Posthuman World: Critical Essays. New Delhi: Oxford University Press.

[5] Berger, A. (2018). Media and Communication researcch methods: An introduction to Qualitative and Quantative Methods. Los Angeles, California: Sage Publications.

[6] Berger, P. L. (1974). Pyramids of Sacrifice. New Year: Basic Books.

[7] Berhnhardt, J. (2021). Keynote Address to Creativity and Culture for Management in Changing World. ICMC. MICA.

[8] Bhargava, Y. (2020, May 06). The Hindu. Retrieved from https://www.thehindu.com/news/national/ethicalhacker-robert-baptiste-elliot- alderson-sees-security-flaws-in-aarogya-setu/article31515292.ece

[9] Birkland, T. (2005). An Introduction to the Policy Process: Theories, Cocnepts and Models of Public PolicyMaking (Second ed.). New York: M.A. Sharpe.

[10] Birkland, T. A. (2005). An Introduction to the Policy Processes: Theories, Concepts and Models of Public Policy-Making. New York: M.E. Sharpe.

[11] Butterfield, S. (2004). US development aid- an historic first: Achievements anf failures in the twentieth century. Westport, CT: Praeger.

[12] Chen, Q., Min, C., Zhang, W., Wang, G., Ma, X., \& Evans, R. (2020). Unpacking the black box: How to promote citizen engagement through government social media during the COVID-19 crisis. In Computers in Human Behavior (Vol. 110). https://doi.org/10.1016/j.chb.2020.106380

[13] Chomsky, N., \& Edward, H. S. (1988). Manufacturing Consent: The Political Economy of the Mass Media. United States: Pantheon Books.

[14] Christakis, N. A. (2013). Lets shake up the Social Sciences . The New York Times, p. B4. Clarance, A. (2020, May 14). BBC. Retrieved from https://www.bbc.com/news/world-asia-india-52659520

[15] Das, D. L. (2000). Practice of Social Research. Jaipr: Rawat Publications.

[16] Das, R., \& Ahmed, W. (2020). Despite concerns, COVID-19 shows how social media hasbecome an essential tool in the democratisation of knowledge. LSE Impact Blog. http://eprints.lse.ac.uk/105443/\%0Ahttps://blogs.lse.ac.uk/impactofsocialsciences/2020/ 06/05/despiteconcerns-covid-19-shows-how-social-media-has-become-an-essential- tool-in-the-democratisation-ofknowledge/\%0Ahttps://arxiv.org/abs/2007.13169

[17] Demuyakor, J. (2020). Social media and COVID-19 pandemic: Enhancing panic or preventing it? International Journal of Humanities, Arts and Social Sciences, 6(5), 211- 222. https://doi.org/10.20469/ijhss.6.20005-5

[18] Depoux, A., Martin, S., Karafillakis, E., Preet, R., Wilder-Smith, A., \& Larson, H. (2020).

[19] The pandemic of social media panic travels faster than the COVID-19 outbreak. Journal of Travel Medicine, 27(3), 1-2. https://doi.org/10.1093/jtm/taaa031

[20] Dept. of Electronics \& IT. (2015). Mins. of Electronics and Information Technology.

[21] Retrieved from https://www.meity.gov.in/writereaddata/files/Approved\%20Social\%20Media\%20Fra mework\%20and\%20Guidelines\%20_2_.pdf

[22] DoT, MoC. (2020, September 15). Ministry of Communication, GOI. Retrieved from https://dot.gov.in/reportsstatistics/quarterly-newsletter-april-june-2020

[23] DOT, MoC, GOI. (2018, November 22). Department of Telecommunications. Retrieved July 12, 2020, from Profile: https://dot.gov.in/profile

[24] Dye, T. R. (2002). Understanding Public Policy (Tenth ed.). Delhi: Pearson Education.

[25] ET Bureau. (2020, March 25). The Economics Time. Retrieved from https://economictimes.indiatimes.com/industry/media/entertainment/media/covid-19- outbreak-ibministry-orders-states-to-facilitate-media- operations/articleshow/74801050.cms?from=mdr

[26] Galtung, J. (1970). Theory and Models of Social Research. London: George Allen and Unwin.

[27] Goswami, S. (2009). Media and Communication Policies in Post-Independent India: Special Reference to Health Communication. London: London School of Economics. 
[28] IANS. (2021). India gets ranked 86 out of 98 nations for its COVID-19 handling. The News Minute. https://www.thenewsminute.com/article/india-gets-ranked-86-out-98-nations- its-covid-19-handling142355

[29] Kumar, R. (2017, Dec 12). Aljazeera. Retrieved from https://www.aljazeera.com/news/2017/12/12/thegrowing-tide-of-fake-news-in-india/

[30] Kushner, J. (2020). The Role of Social Media During a Pandemic. Kohros. https://doi.org/10.1142/9789811230059_0009

[31] Limaye, R. J., Sauer, M., Ali, J., Bernstein, J., Wahl, B., Barnhill, A., \& Labrique, A. (2020).

[32] Building trust while influencing online COVID-19 content in the social media world. The Lancet Digital Health, 2(6), e277-e278. https://doi.org/10.1016/S2589- 7500(20)30084-4

[33] Mathur, K. (2008). From Government to Governance: A Brief Survey of the Indian Experience. Delhi: National Book Trust.

[34] McLuhan, M. (1964). Understanding Media. London: Routledge.

[35] Mehta, P. B. (2003). The Burden of Democracy. New Delhi: Penguin Books India.

[36] MeiTY. (2020, 03 20). Ministry of Electronics \& Informatin Technology, GOI. Retrieved from www.meity.gov.in

[37] MeitY, GOI. (2018, October 25). Ministry of Electronics \& Information Technology. Retrieved February 10, 2020, from Functions of Ministry of Electronics and Information Technology: https://www.meity.gov.in/about-meity/functions-of-meity

[38] Melkote, S. R., \& Steeves, H. L. (2015). Communication for Development: Theory and Practice for Empowerment and Social Justice (Third ed.). Delhi: SAGE Publications.

[39] Menon, G. (2020). Media and entertainment post COVID-19. KPMG. https:/home.kpmg/in/en/home/insights/2020/05/media-and-entertainment-post-covid- 19-the-best-oftimes-the-worst-of-times.html

[40] MIB, GOI. (2018, October 23). Ministry of Information \& Broadcasting, GOI. Retrieved February 20, 2020, from About the Ministry: https://mib.gov.in/about-us/about-the- ministry

[41] MoC. (2020, July 17). Allotment of short cod '14499'. New Delhi: Ministry of Communication, DoT.

[42] Narain, V. (2018). Public Policy A view from South. Cambridge University Press. Neuman, W. (2007). Basics of Social Research Methods: Qualitative and Quantitative

[43] Approaches. Boston: Allyn \& Bacon.

[44] Parthasarathi, V., \& Agarwal, S. (2019). Media Influence Matrix: India. Budapest: CEU Centre for Media, Data and Society (CMDS).

[45] Sagar. (2020, March 31). Caravan. Retrieved January 2021, from https://caravanmagazine.in/media/hoursbefore-lockdown-modi-asked-print-media- owners-editors-refrain-negative-covid-coverage

[46] Shylendra. (2004). The Emerging Governance Paradigm And Its Implicatios For Poverty Alleviation And Equity. Anand: IRMA.

[47] Singh, B. (2020). Media in the time of covid-19. Economic and Political Weekly, 55(16). Singh, S., \& Bagchi, K. (2020). How Internet Platforms Are Combating Disinformation and

[48] Misinformation in the Age of COVID-19. https://www.jstor.org/stable/resrep25418.12

[49] Singha, A. (2021, January 14). Free Press Journal. Retrieved from https://www.freepressjournal.in/india/west-bengal-bjp-tmc-now-engage-in-verbal- duel-over-rights-ofjournalists

[50] Smith, V., \& Wanless, A. (2020). The challenges of communicating during a pandemic.

[51] Carneige Endowment for International Peace. Retrieved Dec 28, 2020, from https://www.jstor.org/stable/resrep25782.4

[52] Stouffer, S. (1962). Social Research to Test Ideas. New York: Free Press of Glencoe. Sudhakar, G. (2015, JulSep). Scientific Research Methodology Vs. Social Science Research

[53] Methodology. MTC Global Journal of Management and Entrepreneurship, 3(6), 36- 40.

[54] UNDP. (1990). Human Development Report 1990: Concept and Measurement of Human Development. New Year.

[55] Xia, B., \& Gong, P. (2015). Review of business intelligence through data analysis.

[56] Benchmarking, 21(2). doi:10.1108/BIJ-08-2012-0050 